Article

\title{
Psychopathological Symptoms and Personality Traits as Predictors of Problematic Smartphone Use in Different Age Groups
}

\author{
Lea-Christin Wickord * and Claudia Quaiser-Pohl (D)
}

check for updates

Citation: Wickord, L.-C.;

Quaiser-Pohl, C. Psychopathological Symptoms and Personality Traits as

Predictors of Problematic

Smartphone Use in Different Age

Groups. Behav. Sci. 2022, 12, 20

https://doi.org/10.3390/bs12020020

Academic Editor: Paul T. Costa, Jr.

Received: 11 December 2021

Accepted: 20 January 2022

Published: 25 January 2022

Publisher's Note: MDPI stays neutral with regard to jurisdictional claims in published maps and institutional affiliations.

Copyright: (c) 2022 by the authors. Licensee MDPI, Basel, Switzerland. This article is an open access article distributed under the terms and conditions of the Creative Commons Attribution (CC BY) license (https:// creativecommons.org/licenses/by/ $4.0 /)$.

\author{
Institute of Psychology, University Koblenz-Landau, 56070 Koblenz, Germany; quaiser@uni-koblenz.de \\ * Correspondence: lwickord@uni-koblenz.de
}

\begin{abstract}
The study investigates psychopathological symptoms and the Big Five personality traits as predictors of "problematic smartphone use" (PSU) in different generational groups. The generational groups were selected to analyze whether the different life stages and developmental tasks that need to be completed have an impact on PSU. The groups were divided into digital immigrants, digital natives, and Generation $\mathrm{Y}$ and $\mathrm{Z}$ as subgroups of digital natives. A total of 399 subjects participated (312 women, 86 men, 1 diverse; mean age $=25.9$; range 14-67; 44 digital immigrants, 355 digital natives, 35 Generation Y, and 320 Generation Z). They completed the ICD-10 Symptom Rating (ISR), the Big Five Inventory-10 (BFI-10), and the Mobile Phone Problematic Use Scale (MPPUS). The results show differences between digital immigrants and digital natives in the expression of PSU, neuroticism, conscientiousness, depression, anxiety, and compulsivity. Concerning Generations Y and Z, differences were only found in the expression of the PSU. Regression revealed that symptoms for obsessive-compulsive disorders, depression, conscientiousness, and gender were significant predictors of PSU. Moderations have shown that being a digital immigrant/native moderates the impact of eating disorders on PSU. Belonging to Generation $\mathrm{Y} / \mathrm{Z}$ moderates the influence of conscientiousness and depression on PSU. Thus, it shows that in different generations, different factors seem to play a role in the development and maintenance of PSU.
\end{abstract}

Keywords: problematic smartphone use; psychopathological symptoms; personality; big five; generations; development

\section{Introduction}

Smartphones are considered among the most widespread and popular communication devices [1,2]. In 2019, around 81.7\% of Germans over the age of 14 owned a smartphone [3]. In this context, it can be seen that the smartphone medium has shaped and changed the existing communication and information landscape enormously. Information and contacts are now easier to access, faster to find, and spread over a larger radius $[4,5]$. Most needs of smartphone users can be satisfied with the help of their smartphones [1]. Smartphones facilitate a variety of life domains, providing, for example, sociability, entertainment, distraction, information gathering, time management, coping strategies, and enacting one's identity [6-10]. Thus, the handy telecommunication device becomes an indispensable part of everyday life [11].

\subsection{Problematic Smartphone Use}

Alongside these positive results, concerns about user overuse and dependency are growing louder. For example, several studies have already found that some users are so influenced by their smartphones that they sense separation anxiety when they do not have the device with them $[12,13]$. This phenomenon can be found under the term problematic smartphone use, where excessive smartphone use is assumed, and symptoms similar to substance-related addictions, functional impairment, and withdrawal are evident [14,15]. Billieux refers to problematic smartphone use (PSU) as "an inability to regulate one's use of 
the smartphone, which eventually involves negative consequences in daily life." [16] (p. 1). Due to the similarity of symptoms to addicts, such as loss of control, mood regulation, or loss of cognitive functioning, the term "smartphone addiction" can be found in many studies $[17,18]$. Smartphone addiction itself refers to an addiction that disrupts users' social connections through excessive and unregulated usage [19]. As Kuyulu and Beltekin point out: "The use of smartphones both gives pleasure to the person as a result of use and saves them from pressure or anxiety. Such reinforcement makes it easy to be addicted to the smartphone" [1] (p. 305). Despite these addiction-like symptoms, it is important to distinguish problematic smartphone use from addiction according to ICD-10 criteria, as the consequences of this do not resemble the intensity and severity of addiction consequences [11]. To avoid pathologizing smartphone use, Long et al. suggest using the term "problematic smartphone use" (PSU) for the phenomenon [20]. This term is also used hereafter. Although the similarity of symptoms does not entirely meet the necessary criteria of addiction, studies showed that PSU could have negative impacts on fatigue, insomnia, diminished immune system, wrist syndrome, neck muscle fatigue, social isolation, family problems, neglect of daily chores, cyberbullying, sexual assault, and school failure [20,21].

When considering PSU, it is crucial to take a more nuanced look at the smartphone because it is not the technological device itself that is addictive, but the range of uses that the smartphone offers, which serve to satisfy needs and which, if misused, make it a space for multiple dependencies [22-25]. In this sense, for example, the need for connection can be liberated by social media platforms, which, however, can have negative consequences for one's emotions, relationships, psychological stability and can even lead to depressive symptoms if consumed excessively [26-28]. In addition, Markowetz determined that the constant digital alertness overtaxes our cognitive, psychological, and social abilities [29]. For these reasons, more and more mass media are covering the gravity of the problem, and studies of the symptoms of overdependence, as well as the development of appropriate measurement tools, are steadily increasing to predict fewer health issues regarding the usage of smartphones $[16,30]$.

\subsection{Mental Health and Psychopathological Symptoms}

Mental health, in particular, plays a significant role when considering PSU. The World Health Organization (WHO) defines mental health as a state of well-being in which the individual is able to use his or her faculties, cope with the regular life stresses, and give back to his or her community and has acknowledged PSU officially as a public health concern [31]. Digitalization and constant accessibility for one's own community, in particular, ensure a "fragmentation of everyday life" and possibly lead to overload [29]. Looking at the current state of research on psychological stress factors in relation to the digitization and the use of new technologies, it is clear that information and communication technologies, in particular, are associated with a range of psychosomatic complaints, signs of stress, exhaustion, and depression [32,33]. These include symptoms such as sleep disturbances, headaches, persistent fatigue, and risky sexual or aggressive behaviors [28,31,34-36]. For example, Sampasa-Kanyinga and Lewis examined the association of time spent on social networking websites and psychological functioning in children and adolescents [37]. They found that poor mental health (self-reported), high levels of psychological overload, harmful stress, and suicidal thoughts were independently associated with spending much time on social media. Moreover, Lee et al. showed that increasing the frequent usage as well as the length of the use was strongly correlated with the gravity of depression and depression severity correlate with PSU [38-40]. Similar correlations, only less pronounced, are also shown for anxiety and its severity [41-44]. The findings of Kim, Seo et al. show that smartphone use to reduce negative emotions mediates the association of depression and anxiety severity and PSU [45]. Subsequently, Elhai et al. revealed that behavioral activation mediates the correlation between depression and PSU [42]. Authors Kempf et al. found initial evidence of a difference in OCD according to the duration of smartphone use [46]. A correlation between PSU and OCD has been shown several times before [47-49]. Research has also 
found multiple correlations with PSU for somatization $[47,49,50]$. Tayhan Karthal et al. were able to show that PSU correlates with obesity and, similarly, that social media use as a part of PSU correlates with eating disorders [51-53]. Due to these correlations, a greater understanding of the reasons for maladaptive and problematic smartphone usage is required to prevent psychological health issues [14]. Most of these studies show correlations between psychopathological symptoms and PSUs without specifying a direction of action. However, some studies have also shown that psychopathological symptoms are predictors of PSU, as they lead to increased consumption of the medium $[30,47,54]$. For this reason, this study will also focus on the use of symptoms as predictors. The development of mental health issues is multifaceted and cannot be generalized. However, the complexity and the multitude of influencing factors, among them especially the personality of the individuals, represents a significant factor.

\subsection{Personality and PSU}

The increase in general psychological distress and the increase in smartphone use can be related and analyzed in the context of personality $[55,56]$. Personality is defined as the set of characteristics of an individual that determine how we perceive our environment and communicate with it [57]. One of the best-known personality models is the Big Five personality model with the five dimensions neuroticism or emotional instability, extraversion, openness to experience, agreeableness, and conscientiousness [58]. The relationship between personality and PSU has already been widely researched to determine whether specific personality traits exist that predispose smartphone users to adopt addictive tendencies or problematic usage patterns [59]. Billieux was the first to identify individual risk factors and mental characteristics associated with PSU, including personality traits [16]. The Big Five personality traits [60] have been examined in many studies on PSU [61-64]. It has been consistently found that PSU is associated with high levels of the dimensions of neuroticism and extraversion [65-69]. Furthermore, a relationship between low expressions on the conscientiousness and agreeableness dimensions and PSU has been demonstrated $[14,59,61,64,70]$, and it was also shown that openness negatively predicted or correlated with PSU $[63,71,72]$.

\subsection{The Generational Perspective}

In addition to personality, another factor that can be cited to examine smartphone exposure is age or the generation you grew up in. Most studies focus on adolescents and young adults who belong to the generation of digital natives when investigating PSU. Digital natives are defined as the young generation born after 1980 who have grown up with various IT systems from birth. Accordingly, they find digital devices easy to use and are open to technical innovations [73]. Since they are still considered the main consumers, these groups offer important clues for investigating PSU. Nevertheless, it is just as important to include other generations in the focus of the studies, primarily the so-called digital immigrants, i.e., the generation of parents of digital natives and older generations who were confronted with digital tools such as smartphones later in life, to investigate how these generations suffer from PSU [74]. While digital natives take smartphones for granted, many digital immigrants take a more critical view of constant usage behavior. It is therefore not surprising that the two groups also cite different reasons for PSU. While digital immigrants believe that PSU arises due to a lack of control by the individual user and is thus due to intrinsic characteristics, digital natives see the smartphone as the main communication tool at the center of their lives and therefore see PSU as an unavoidable evil that has arisen extrinsically due to the environment created by the smartphone (ibid).

In addition to exploring digital natives and digital immigrants, it is also necessary to look at the subgroups within digital natives, more specifically, Generations Y and Z. Depending on the definition, Generation Y includes those born between 1980 and 1996, while Generation Z includes those born between 1997 and 2010 [75]. While Generation Y, which is now 25 and older, is starting a more settled life due to age with more constant living 
circumstances such as a steady job, a long steady relationship, and slowly making fewer new friends [76], Generation $Z$ is currently in early adolescence to young adulthood and has essential developmental steps to complete towards an independent life [77]. Because of these differences in developmental tasks, it is essential to examine how these subgroups suffer from PSU. Research has shown that younger individuals are more likely to develop PSU [78]. Cerniglia et al. describe that adolescents are more prone to PSU and reason that the cerebral cortex is not sufficiently developed as well as there may be a mismatch between the development of different brain areas, which can lead to both affective and behavioral dysregulation [79]. Therefore, it is important to differentiate the behavior between these two subgroups.

\subsection{Underlying Model}

Theoretically, the study presented here refers to the Pathway Model [14]. According to the authors, various pathways exist that lead to or are associated with problematic smartphone use: the reassurance-seeking pathway involves regularly checking notifications to gain social reassurance through contacts. People with lower self-esteem, higher anxiety, loneliness, and depression are associated with the reassurance-seeking pathway. The fear of missing out pathway (FoMO; the fear of missing out) is also related to smartphone checking and notifications. Other pathways in the model include the extraversion pathway, which includes symptoms of social dependence through which individuals regularly seek to establish new relationships and contacts, and the impulsivity pathway, which is characterized by a lack of self-control and includes antisocial personality traits, disinhibition, and attention deficits. As can be seen from the model, it refers both to personality factors and psychopathological aspects, which is why these two factors will be the main components of the study.

The generational approach is used because digital development has progressed immensely in recent years and thus represents a generation-shaping consideration. While older generations have only gradually integrated emerging technologies into their lives, younger generations have grown up with these devices from the beginning, leading to a changed attitude towards these gadgets $[73,74]$. For this reason, generational work looks at how these aspects change over the course of a lifetime. Generational cohorts can make visible how specific formative experiences (changes regarding the world, economical, technological, and social changes) affect the lives and views of individuals [75].

Therefore, the article shows the factors influencing personality and psychopathology on problematic smartphone use. For the first time, the differences in the predictors of smartphone use between generations and the corresponding developmental stages in which the individuals in the respective age groups find themselves are examined. Thus, beyond the existing research, the article offers a significant contribution to the explanation of predictors of problematic smartphone use.

\subsection{Hypotheses}

As previous studies have already shown $[73,74]$, the smartphone is perceived differently by digital natives and digital immigrants. It is hypothesized that there are differences between digital immigrants and digital natives in the expression of PSU (H1).

Additionally, previous studies have shown that younger individuals in particular develop PSU [79]. For this reason, the subgroups of digital natives, Generation Y and Generation Z, will be looked at more closely with regard to PSU, as these generations are each going through different developmental tasks $[77,78]$. Therefore, we assume that there are also differences between Generation Y and Generation Z in the expression of PSU (H2).

Consistent with previous research [47,61-64], personality traits and psychopathological symptoms should have an impact on PSU; therefore, we hypothesize that PSU correlates with personality and the presence of psychopathological symptoms (H3). As described by Ahn and Jung and Prensky, digital immigrants and digital natives differ strongly in their usage behavior and their view towards smartphones, and the reasons for the emergence of PSU [73,74]. For this reason, it is hypothesized that PSU will correlate with different 
personality traits and psychopathological symptoms in digital immigrants (persons over 40 years of age) than in digital natives (persons under 40 years of age) (H4).

In addition, digital natives can be divided into Generations $\mathrm{Y}$ and $\mathrm{Z}$. These, in turn, differ significantly in their lifestyles and the development tasks they have to master $[76,77]$, and as Echeburúa and de Corral were able to determine, younger people are more inclined to form PSU [78]. For this reason, the hypothesis is proposed that PSU correlates with different personality traits and psychopathological symptoms in members of Generation $Y$ (persons over 25 years of age) than in members of Generation $\mathrm{Z}$ (persons under 25 years of age) (H5).

\section{Materials and Methods}

\subsection{Participants and Procedure}

The study sample consists of a total of 399 subjects $(n=399)$. The study included 312 females $(n=312), 86$ males $(n=86)$, and 1 person who assigned himself to be "diverse" $(n=1)$. The large difference between the sexes can be explained by the fact that a large proportion of the subjects are psychology students and that they are predominantly female. Nevertheless, it can be seen that the male gender is sufficiently represented with 86 subjects and that the sample distribution of the mean is approximately normally distributed [80,81]. The average age was 25.9 years $\left(M_{\text {age }}=25.9\right)$ with a minimum of 14 years $($ Min $=14)$ and a maximum of 67 years $(M a x=67)$. In this regard, the sample had a standard deviation of $11.1\left(S D_{\text {age }}=11.1\right)$. In terms of generations, 44 members of the digital immigrants generation $(n=44), 355$ members of the digital natives generation $(n=355), 35$ members of Generation Y $(n=35)$, and 320 members of Generation Z $(n=320)$ participated. Regarding the occupation, a total of 255 students participated in the study $(n=256)$. This was followed by the group of working people with 96 participants $(n=96), 44$ pupils $(n=44)$, and only one participant without employment $(n=1)$.

Subjects were recruited through the network of the University of Koblenz Landau. To increase the incentive to participate in the survey, 10 EUR 20 Zalando vouchers were raffled among all participants. The entire data collection was carried out online via the platform SoSciSurvey. The survey period was from 11 January 2021 to 24 January 2021. During this period the second German lockdown due to the COVID-19 pandemic also took place from December 2020 to May 2021. The online survey took approximately $15 \mathrm{~min}$ to complete and consisted of a questionnaire battery consisting of a sociodemographic questionnaire, the BFI-10 questionnaire [82], the MPPUS [30], followed by the ISR [83]. All questions were asked in German.

\subsection{Material and Measures}

The materials used are standardized questionnaires with all information provided in the self-assessment. First, sociodemographic data (gender, age, state, occupation, and smartphone-usage time) were collected.

\subsection{MPPUS-27}

The Mobile Phone Problematic Use Scale (MPPUS-27) by Bianchi and Phillips is used to investigate problematic smartphone use and consists of 27 items [30]. The German version of the MPPUS used in this study is a self-translation that was tested and created using the back-translation method and can be found in Appendix A [84]. Through the ten-point Likert scale from not at all true (1) to completely true (10), the aspects of tolerance, negative effects on everyday life, escape from problems, loss of control, cravings, and withdrawal in the social, family, and professional context are queried. In addition, there is the question about the time factor, i.e., the duration of smartphone use and how much time is lost through it. The MPPUS was calculated using the sum score from all $27 \mathrm{items}$ and has an excellent internal consistency in this study with a value of Cronbach's alphas of $>0.9$ [85]. 


\subsection{ISR}

The ICD-10 Symptom Rating (ISR) by Tritt et al. is a self-assessment regarding the status and severity of psychopathological symptoms [83]. It is based on the International Statistical Classification of Diseases and Related Health Problems. As such, it serves to standardize and simplify medical diagnoses by defining the symptoms and diagnoses of specific diseases. The ISR consists of five scales, each represented by three to four items and formed using the mean. The scales include depression, anxiety disorders, obsessivecompulsive disorders, somatizations, and eating disorders. The rating uses a five-point scale from strongly disagree (0) to strongly agree (4). The ISR has excellent to acceptable internal consistencies in this study with Cronbach's alpha values of $>0.8$ for depression, $>0.8$ for eating disorders, $>0.8$ for anxiety disorders, $>0.8$ for obsessive-compulsive disorders, and $>0.8$ for somatizations [85].

\subsection{BFI-10}

The BFI-10 [82] measures the Big Five personality traits of extraversion, neuroticism, agreeableness, conscientiousness, and openness. The BFI-10 is based on the BFI with originally 44 items [86], which was shortened to 10 items for economic reasons. The ten items of the inventory consist of two items per dimension, which are represented by one positive and one negative item. The ten questions are answered with the aid of a five-point rating scale ranging from "strongly disagree" (1) to "strongly agree" (5) and the five scales are formed with the use of the mean value. The average time required to complete the inventory is one minute [82]. The BFI-10 has good to unacceptable internal consistencies in this study with Cronbach's alpha values of $>0.6$ for neuroticism, $>0.5$ for conscientiousness, $>0.6$ for openness, $>0.3$ for agreeableness, and $>0.8$ for extraversion [83]. The Cronbach's alpha values mentioned here should be viewed with caution due to the low number of items per dimension and thus low heterogeneity, which is why Rammstedt et al. prefer retest reliability to internal consistency. In the original study by the authors of the test, this was 0.75 measured over a period of 6 weeks, but could not be carried out here due to a lack of repeated measurements [87].

\subsection{Statistical Analysis}

Data analysis for this study was performed using IBM SPSS version 27 statistical software. The data analysis consists of descriptive statistics (means and standard deviations) and inferential statistical analysis procedures, calculation of mean differences between generations, primarily multiple linear regressions on the variables using PSU (measured by the MPPUS) as a criterion, and participants' psychopathological symptoms (measured by the ISR) and personality traits (measured by the BFI-10) as predictors (a) for the entire sample and (b) moderation analysis for testing different effects for digital natives and digital immigrants and (c) moderation analysis for testing different effects for Generation $Y$ and Generation Z.

\section{Results}

In Table 1, the bivariate correlations between all variables used can be seen for the entire data set.

Table 1. Bivariate correlations after Pearson with ISR, BFI-10, and MPPUS (total sample).

\begin{tabular}{|c|c|c|c|c|c|c|c|c|c|c|}
\hline & 1 & 2 & 3 & 4 & 5 & 6 & 7 & 8 & 9 & 10 \\
\hline \multicolumn{11}{|l|}{ BFI } \\
\hline \multicolumn{11}{|l|}{ Extraversion } \\
\hline Neuroticism & $-0.222 * *$ & & & & & & & & & \\
\hline Openness & -0.011 & -0.038 & & & & & & & & \\
\hline
\end{tabular}


Table 1. Cont.

\begin{tabular}{|c|c|c|c|c|c|c|c|c|c|c|}
\hline & 1 & 2 & 3 & 4 & 5 & 6 & 7 & 8 & 9 & 10 \\
\hline Conscientiousness & 0.044 & -0.085 & 0.092 & & & & & & & \\
\hline Agreeableness & 0.091 & -0.057 & 0.016 & $0.147^{* *}$ & & & & & & \\
\hline MPPUS & -0.015 & $0.267 * *$ & 0.088 & $-0.340 * *$ & -0.078 & & & & & \\
\hline \multicolumn{11}{|l|}{$\begin{array}{l}\text { Psychopathological } \\
\text { Symptoms }\end{array}$} \\
\hline Depression & $-0.154^{* *}$ & $0.378 * *$ & 0.040 & $-0.274^{* *}$ & $-0.156^{* *}$ & $0.410^{* *}$ & & & & \\
\hline Anxiety & $0.303 * *$ & $0.532 * *$ & 0.043 & $-0.212^{* *}$ & $-0.126^{*}$ & $0.341 * *$ & $0.508^{* *}$ & & & \\
\hline $\begin{array}{l}\text { Obsessive- } \\
\text { Compulsive }\end{array}$ & $-0.120 *$ & $0.388 * *$ & 0.052 & $-0.128 *$ & -0.029 & $0.327 * *$ & $0.446 * *$ & $0.561 * *$ & & \\
\hline Somatization & $-0.137 * *$ & $0.331 * *$ & 0.072 & -0.073 & $-0.150 * *$ & $0.297 * *$ & $0.397^{* *}$ & $0.506^{* *}$ & $0.392 * *$ & \\
\hline Eating Disorder & 0.015 & $0.159 * *$ & 0.066 & 0.026 & -0.053 & $0.233^{* *}$ & $0.304^{* *}$ & $0.247^{* *}$ & $0.239 * *$ & $265^{* *}$ \\
\hline
\end{tabular}

Table 2 shows the mean values and standard deviations of the raw scores for the MPPUS and the subscales for the ISR and the BFI-10 for the entire sample and broken down by the subgroups of digital immigrants and digital natives divided into Generations $\mathrm{Y}$ and $\mathrm{Z}$.

Table 2. Descriptive statistics for ISR, BFI-10, and MPPUS (total sample, digital immigrants, digital natives, Generation Y, and Generation Z).

\begin{tabular}{|c|c|c|c|c|c|}
\hline & $\begin{array}{l}\text { Total Sample } \\
\quad(n=399)\end{array}$ & $\begin{array}{l}\text { Digital Immi-grants } \\
(n=44)\end{array}$ & $\begin{array}{l}\text { Digital Natives } \\
\quad(n=355)\end{array}$ & $\begin{array}{c}\text { Generation } Y \\
\quad(n=35)\end{array}$ & $\begin{array}{l}\text { Generation } \mathrm{Z} \\
\quad(n=320)\end{array}$ \\
\hline & \multicolumn{5}{|c|}{ Mean (SD) } \\
\hline \multicolumn{6}{|l|}{ Personality } \\
\hline Neuroticism & $3.04(0.97)$ & $2.60(1.06)$ & $3.10(0.95)$ & $2.96(0.92)$ & $3.11(0.95)$ \\
\hline Agreeableness & $3.33(0.78)$ & $3.33(0.82)$ & $3.34(0.78)$ & $3.27(0.68)$ & $3.34(0.79)$ \\
\hline Conscientiousness & $3.53(0.82)$ & $3.90(0.66)$ & $3.49(0.83)$ & $3.54(0.69)$ & $3.48(0.85)$ \\
\hline Openness & $3.65(0.95)$ & $3.48(0.91)$ & $3.67(0.95)$ & $3.71(0.98)$ & $3.66(0.95)$ \\
\hline Extraversion & $3.47(0.95)$ & $3.50(0.82)$ & $3.47(0.97)$ & $3.57(0.98)$ & $3.45(0.97)$ \\
\hline \multicolumn{6}{|c|}{ Psychopathological Symptoms } \\
\hline Depression & $2.42(0.94)$ & $1.80(0.87)$ & $2.5(0.92)$ & $2.41(0.86)$ & $2.51(0.93)$ \\
\hline Obsessive-Compulsive & $1.86(0.92)$ & $1.53(0.85)$ & $1.9(0.92)$ & $1.89(0.99)$ & $1.91(0.92)$ \\
\hline Anxiety & $2.00(0.94)$ & $1.62(0.78)$ & $2.05(0.95)$ & $1.96(1.00)$ & $2.06(0.94)$ \\
\hline Eating Disorder & $1.89(1.03)$ & $1.66(0.75)$ & $1.92(1.05)$ & $1.87(0.98)$ & $1.92(1.06)$ \\
\hline Somatization & $1.42(0.79)$ & $1.29(0.54)$ & $1.44(0.81)$ & $1.42(0.83)$ & $1.44(0.81)$ \\
\hline \multicolumn{6}{|l|}{ PSU } \\
\hline MPPUS & $107.04(36.34)$ & $69.23(29.18)$ & $111.63(34.39)$ & $96.31(29.80)$ & $113.31(34.48)$ \\
\hline
\end{tabular}

The conclusion about differences $(\mathrm{H} 1$ and $\mathrm{H} 2)$ are drawn from t-tests. The results confirm that there are statistically significant differences between digital immigrants and digital natives in the expression of PSU (H1) $t(398)=7.854, p<0.001, d=1.381$, the personality traits neuroticism $t(397)=3.201, p=0.001, d=0.563$ and conscientiousness $t(397)=-3.152, p=0.002, d=0.554$, as well as in the psychopathological symptoms of depression $t(396)=4.789 p<0.001, d=0.853$, anxiety $t(396)=2.882, p=0.004, d=0.513$, and compulsivity $t(396)=2.527, p=0.012, d=0.450$. Concerning Generations $\mathrm{Y}$ and $\mathrm{Z}(\mathrm{H} 2)$, significant mean differences were only found in the expression of the PSU $t(353)=2.619$, $p=0.009, d=0.461$. 
Afterward, we calculated a multiple linear regression analysis using the inclusion method. Regression was first performed on the entire data set (H3). Then, moderation analyses were run to see if there were different effects of predictors according to digital natives and digital immigrants (H4). The same procedure was then performed for Generations $\mathrm{Y}$ and $\mathrm{Z}$ (H5). In all regressions, gender was included in the analysis as a control variable.

The prerequisites for the analysis were checked and fulfilled.

For H3, one subject was excluded from the calculation as an outlier. Regression for $\mathrm{H} 3$ revealed that psychopathological symptoms for obsessive-compulsive disorders, depression, the personality trait conscientiousness, and gender were significant predictors of PSU (Table 3). The psychopathological symptoms for eating disorders, anxiety, and somatization, as well as the personality traits extraversion, neuroticism, openness, and agreeableness, could not explain any incremental variance and were therefore not included further.

Table 3. Predictors of PSU.

\begin{tabular}{|c|c|c|c|c|c|}
\hline & \multicolumn{5}{|c|}{ Total Sample $(n=398)$} \\
\hline & B & $t$ & $p$ & $R^{2}$ & Adjusted $R^{2}$ \\
\hline \multicolumn{6}{|l|}{ Personality } \\
\hline Neuroticism & 0.081 & 1.560 & 0.120 & 0.304 & 0.284 \\
\hline Agreeableness & -0.006 & -0.141 & 0.888 & & \\
\hline Conscientiousness & -0.282 & -6.170 & $<0.001$ & & \\
\hline Openness & 0.078 & 1.791 & 0.074 & & \\
\hline Extraversion & 0.062 & 1.371 & 0.171 & & \\
\hline \multicolumn{6}{|c|}{ Psychopathological Symptoms } \\
\hline Depression & 0.166 & 3.063 & 0.002 & & \\
\hline Obsessive-Compulsive & 0.122 & 2.243 & 0.025 & & \\
\hline Anxiety & 0.009 & 0.142 & 0.887 & & \\
\hline Eating Disorder & 0.091 & 1.960 & 0.051 & & \\
\hline Somatization & 0.101 & 1.963 & 0.050 & & \\
\hline Gender & -0.113 & -2.472 & 0.014 & & \\
\hline
\end{tabular}

The four significant predictors explained $30 \%$ of the variance in $\operatorname{PSU}(\mathrm{F}(11,385)=15.264$, $p<0.001, R^{2}=0.304$ ), which corresponds to a high variance explanation (ibid.).

For H4, moderation analysis was calculated for the two generations of digital immigrants (individuals over 40 years of age) and digital natives (individuals under 40 years of age). One subject from digital natives was excluded from the calculation as an outlier. The moderation analysis was run to determine whether the interaction between generation and psychopathological symptoms and personality traits predicts PSU. Results show that the generation moderated the effect between eating disorder symptoms and PSU significantly, $\left.\mathrm{F}(13,383)=17.452, p=0.006, \Delta R^{2}=0.013\right)$ predicting $1.3 \%$ of the variance, as seen in Table 4.

Table 4. Moderation for digital natives and digital immigrants.

\begin{tabular}{|c|c|c|c|c|}
\hline & \multicolumn{4}{|c|}{ Digital Natives $(n=354) /$ Digital Immigrants $(n=44)$} \\
\hline & ß & $t$ & $p$ & $\Delta R^{2}$ \\
\hline \multicolumn{5}{|l|}{ Personality } \\
\hline Generation*Neuroticism & 0.081 & 0.715 & 0.475 & 0.001 \\
\hline Generation*Agreeableness & 0.153 & 0.867 & 0.386 & 0.001 \\
\hline
\end{tabular}


Table 4. Cont.

\begin{tabular}{|c|c|c|c|c|}
\hline & \multicolumn{4}{|c|}{ Digital Natives $(n=354) /$ Digital Immigrants $(n=44)$} \\
\hline & B & $t$ & $p$ & $\Delta R^{2}$ \\
\hline Generation*Conscientiousness & 0.046 & 0.186 & 0.852 & $<0.001$ \\
\hline Generation*Openness & -0.214 & -1.301 & 0.194 & 0.003 \\
\hline Generation*Extraversion & -0.141 & -0.772 & 0.441 & 0.001 \\
\hline \multicolumn{5}{|l|}{ Psychopathological Symptoms } \\
\hline Generation*Depression & -0.012 & -0.121 & 0.904 & $<0.001$ \\
\hline Generation*Obsessive-Compulsive & -0.072 & -0.832 & 0.406 & 0.001 \\
\hline Generation*Anxiety & -0.101 & -1053 & 0.293 & 0.002 \\
\hline Generation*Eating Disorder & 0.272 & 2.762 & 0.006 & 0.013 \\
\hline Generation*Somatization & -0.048 & -0.448 & 0.655 & $<0.001$ \\
\hline
\end{tabular}

* indicates the interaction between variables.

Figure 1 shows the interaction plot of the relationship between eating disorder symptoms and PSU by generation.

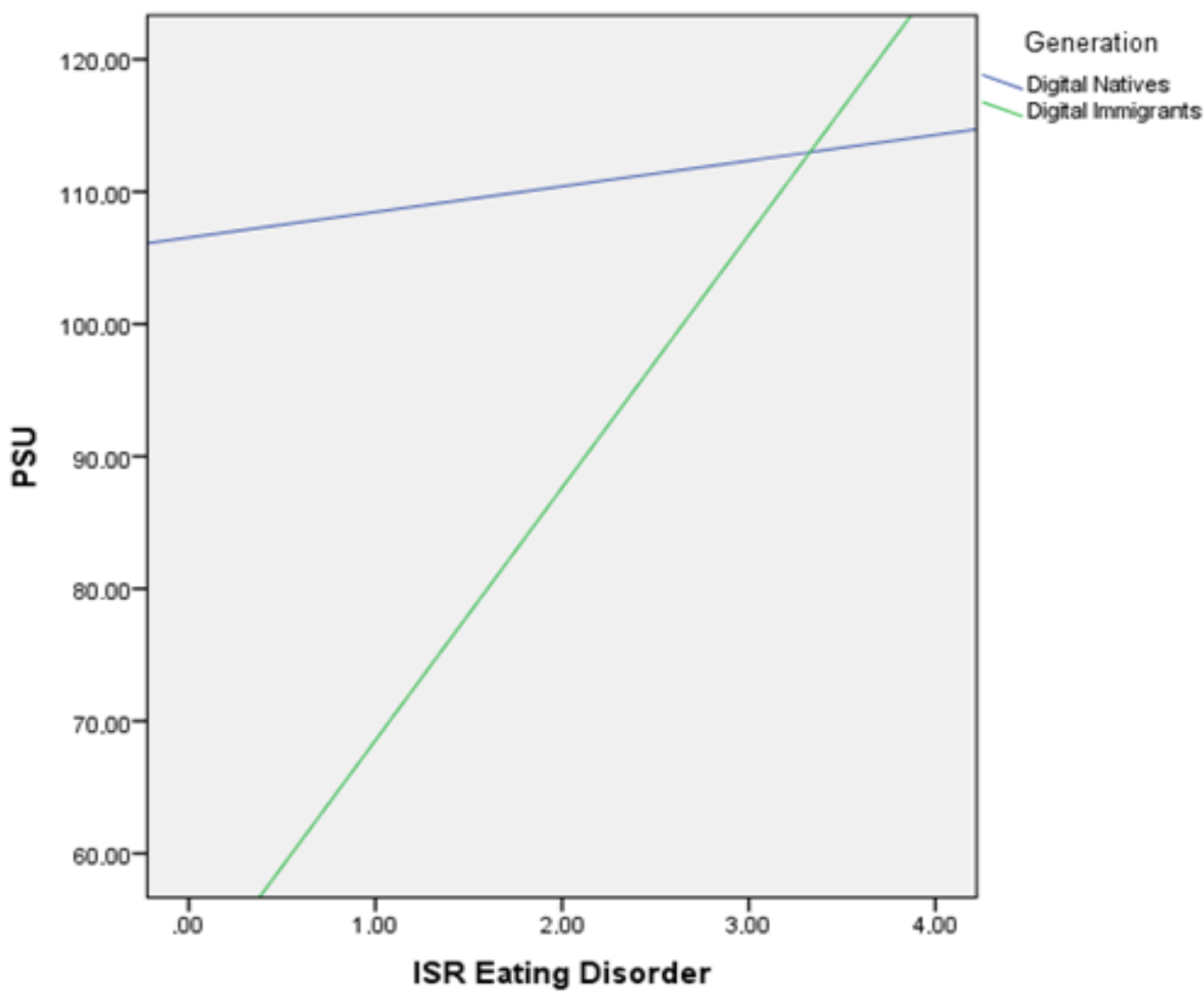

Figure 1. Interaction plot between eating disorder symptoms and PSU for digital natives and digital immigrants.

To answer H5, moderation analysis was again calculated for the two Generations $\mathrm{Y}$ (persons over 25 years) and $\mathrm{Z}$ (persons under 25 years). One subject from Generation $\mathrm{Z}$ was excluded from the calculation as an outlier. The moderation analysis was run to determine whether the interaction between generation and psychopathological symptoms and personality traits predicts PSU. Results show that the generation moderated the effect 
between conscientiousness $\left(\mathrm{F}(13,339)=11.521, p=0.001, \Delta R^{2}=0.022\right)$ as well as depression symptoms $\left(\mathrm{F}(13,339)=10.834, p=0.035, \Delta R^{2}=0.009\right)$ and PSU significantly, predicting $2.2 \%$ of the variance for conscientiousness and $0.9 \%$ for depression symptoms, which corresponds to a small variance explanation for conscientiousness (ibid.), as seen in Table 5 .

Table 5. Moderation for Generation Y and Generation Z.

\begin{tabular}{|c|c|c|c|c|}
\hline & \multicolumn{4}{|c|}{ Generation $Y(n=319) /$ Generation $Z(n=35)$} \\
\hline & B & $t$ & $p$ & $\Delta R^{2}$ \\
\hline \multicolumn{5}{|l|}{ Personality } \\
\hline Generation*Neuroticism & -0.200 & -1.261 & 0.208 & 0.003 \\
\hline Generation*Agreeableness & 0.180 & 0.786 & 0.432 & 0.001 \\
\hline Generation ${ }^{*}$ Conscientiousness & 0.783 & 3.300 & 0.001 & 0.022 \\
\hline Generation*Openness & -0.131 & -0.696 & 0.487 & 0.001 \\
\hline Generation*Extraversion & -0.034 & -0.189 & 0.850 & $<0.001$ \\
\hline \multicolumn{5}{|l|}{ Psychopathological Symptoms } \\
\hline Generation*Depression & -0.294 & -2.122 & 0.035 & 0.009 \\
\hline Generation*Obsessive-Compulsive & -0.055 & -0.533 & 0.594 & 0.001 \\
\hline Generation*Anxiety & -0.111 & -1.051 & 0.294 & 0.002 \\
\hline Generation*Eating Disorder & -0.077 & -0.754 & 0.452 & 0.001 \\
\hline Generation*Somatization & -0.035 & -0.374 & 0.709 & $<0.001$ \\
\hline
\end{tabular}

${ }^{*}$ indicates the interaction between variables.

Figure 2 shows the interaction plot of the relationship between conscientiousness as well as depression symptoms and PSU by generation.
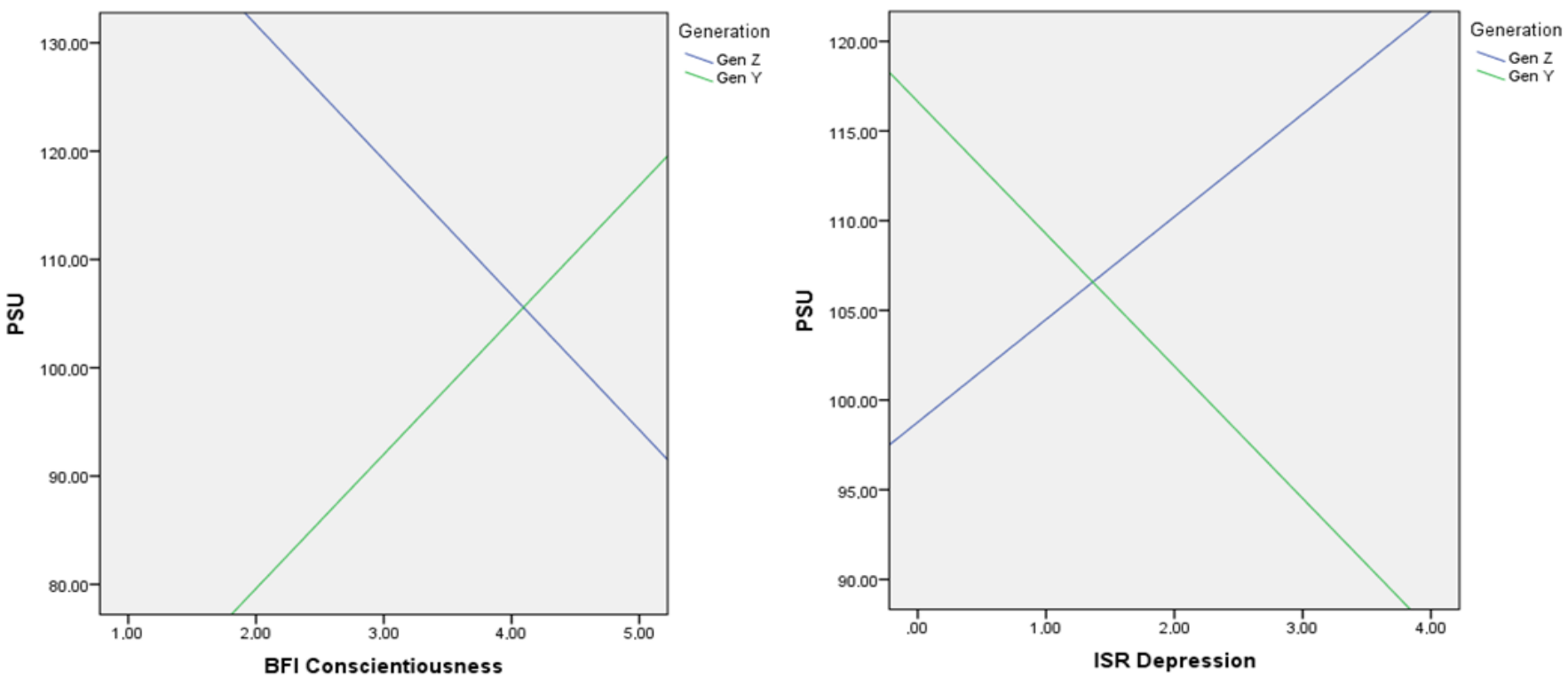

Figure 2. Interaction plot between conscientiousness and PSU and depression and PSU for Generation $\mathrm{Y}$ and Generation Z.

\section{Discussion}

The present study dealt with the psychopathological and personality-related predictors of problematic smartphone use in different generational groups.

The results of $\mathrm{H} 1$ show differences between digital immigrants and digital natives in the expression of PSU, neuroticism, conscientiousness, depression, anxiety, and com- 
pulsivity. Concerning H2, for Generations $\mathrm{Y}$ and $\mathrm{Z}$, differences were only found in the expression of the PSU. Regression for $\mathrm{H} 3$ revealed that psychopathological symptoms for obsessive-compulsive disorders and depression, the personality trait conscientiousness, and gender were significant predictors of PSU. Moderations have shown that being a digital immigrant or digital native moderates the impact of eating disorders on PSU (H4). Belonging to Generation Y or Generation $\mathrm{Z}$ moderates the influence of conscientiousness and depression on PSU (H5). Thus, it shows that in different generations, different factors seem to play a role in the development and maintenance of PSU.

These results are consistent with existing research. First, the differences in the generations ( $\mathrm{H} 1$ and $\mathrm{H} 2)$ can be explained by the fact that individuals are in different stages of life and thus cope with different developmental tasks [76,77].

Regarding the results of $\mathrm{H} 3$, correlates and the effect as a predictor of depression or depressive symptoms as well as symptoms of OCD have been demonstrated several times in research [15,39,40,47-49]. In this context, smartphones are used as a dysfunctional coping strategy to distract oneself from negative emotions and escape from this affective state $[28,87,88]$. In terms of personality factors, low conscientiousness is associated with lower achievement orientation and poorer organizational skills. Accordingly, it is easier for them to lose themselves in the endless possibilities of the smartphone and to tend toward PSU $[89,90]$.

Looking at the moderation, it becomes apparent that the generational groups moderate the effect of psychopathological symptoms of eating disorders on PSU. While PSU is consistently elevated for digital natives, digital immigrants are shown to be more prone to PSU when they have more severe eating disorder symptoms. Since this is a new finding, we can only speculate about the reasons for this. One possible reason could be that digital immigrants with eating disorder symptoms are more likely to withdraw and, in line with the Pathway Model, more likely to use the smartphone [14].

Looking at the moderation, it becomes apparent that the generational groups moderate the effect of psychopathological symptoms of depression on PSU. While Generation Z individuals with depressive symptoms tend to have more severe PSU, the reverse is true for Generation $Y$ individuals. Persons of this generation with depressive symptoms tend to have lower PSU. One possible reason for this could be that Generation Y tends to withdraw, while Generation Z, in line with the Pathway Model, tends to seek reassurance from their smartphones [14].

Another moderation result is that generational groups are found to moderate the effect of the personality trait conscientiousness on PSU. While conscientious individuals of Generation Z tend to be less inclined to PSU, the effect for Generation y is exactly the opposite. The more conscientious someone is, the stronger PSU is. One possible reason for this could be that people in Generation $\mathrm{Z}$ are still at school or studying and the smartphone is more of a nuisance, which is why they have to discipline themselves not to use it. Generation Y, on the other hand, is usually in the middle of their working lives and has both professional and private obligations, which is why conscientious people always have their smartphone with them and use it as much as possible in order to be able to react to every obligation.

An important aspect to be considered is the confounding of the generation with the developmental phase and thus the problem of cross-sectional bias. Certain psychological symptoms occur more frequently in adolescence than in adulthood (see the tests conducted for mean differences, particularly between digital natives and digital immigrants). Accordingly, it is possible that the different relevance and expression depending on the generation also has an impact on what influences the PSU. In that sense, it could be assumed that if a disorder occurs less frequently in one generation per se, it differentiates better there and is thus a better predictor. 


\section{Limitations}

The study suffers from a few limitations. One is that the survey was self-reported, which could lead to a biased picture. In addition, the sample sizes of the subgroups differ greatly; the Generation Y group, in particular, is very small and does not fulfill the statistical power, which means that a generalization of the results is only possible to a limited extent. Thus, future studies should aim for groups of equal size. In addition, it should be noted that only slightly less than a quarter of the subjects were male, which means that the results can be used primarily to describe the factors influencing PSU in women. Moreover, the SARS-CoV pandemic can be expected to exacerbate the increase in psychopathological symptoms and PSU as social interactions shift from the analog to the digital world, which means that outcomes must always be viewed in light of the exceptional temporal situation. In the future, it will be important to conduct prospective longitudinal studies on the topic in order to be able to show representative results with causal directions and additionally, as described before, to better control the confounding between the respective development phases and the generation.

\section{Conclusions}

The present study should first contribute to investigating different generation-specific subgroups to identify PSU predictors specifically. It could be shown that in different generations, different predictors play an important role, which indicates a relationship between developmental phenomena and clinical manifestations and are also evidence of the interplay of age-related (adolescence vs. early adulthood) and epochal-historical developmental influences (degree of digitalization of society) [91].

The topicality of the issue was highlighted not least by the recent Facebook scandals, through which it became known that the Facebook corporation knew and willingly accepted the negative effects on young people's mental health [92]. Given this information to work on the specific predictors according to the respective life stages and developmental tasks to be completed, the smartphone can be a healthy enrichment and simplification of daily life without ending in excessive use or problematic dependence.

Author Contributions: Conceptualization, L.-C.W. and C.Q.-P.; methodology, L.-C.W.; software, L.-C.W.; validation, L.-C.W.; formal analysis, L.-C.W.; investigation, L.-C.W.; resources, L.-C.W. and C.Q.-P.; data curation, L.-C.W.; writing-original draft preparation, L.-C.W.; writing-review and editing, L.-C.W. and C.Q.-P.; visualization, L.-C.W.; supervision, C.Q.-P.; project administration, L.-C.W. All authors have read and agreed to the published version of the manuscript.

Funding: This research received no external funding.

Institutional Review Board Statement: The study performed here was performed in compliance with the guidelines of the declaration of Helsinki. The entire study was reviewed by the Local Ethics Committee (LEK) of the Department of Psychology at the University of Koblenz Landau and was examined with regard to the ethical justifiability of the aims and procedures.

Informed Consent Statement: Informed consent was obtained from all subjects involved in the study.

Data Availability Statement: The data used to analyze the results reported here are available for public review at https://mfr.osf.io/render?url=https $\% 3 \mathrm{~A} \% 2 \mathrm{~F} \% 2 \mathrm{Fosf} .10 \% 2 \mathrm{~F} 8 \mathrm{~s} 9 \mathrm{vn} \% 2 \mathrm{Fdownload}$ (accessed on 10 December 2021).

Acknowledgments: This research did not receive any specific grant from funding agencies in the public, commercial, or not-for-profit sectors.

Conflicts of Interest: The authors declare no conflict of interest.

\section{Appendix A}

German version of the MPPUS created using the back-translation method

1. Ich kann nie genug Zeit mit meinem Smartphone verbringen. 
2. Ich habe mein Smartphone benutzt, um mich besser zu fühlen, wenn ich mich schlecht fühlte.

3. Ich finde mich in Situationen wieder, in denen ich von meinem Smartphone eingenommen bin, obwohl ich andere Dinge tun sollte und das verursacht Probleme.

4. Alle meine Freunde besitzen ein Smartphone.

5. Ich habe versucht vor anderen zu verbergen, wie viel Zeit ich mit meinem Smartphone verbringe.

6. Ich schlafe weniger aufgrund der Zeit, die ich mit meinem Smartphone verbringe.

7. Ich habe Smartphonerechnungen erhalten, die ich mir nicht leisten konnte.

8. Wenn ich für einige Zeit keinen Empfang auf meinem Smartphone habe, beschäftigen mich die Gedanken, einen Anruf oder eine Nachricht zu verpassen.

9. Manchmal, wenn ich mit dem Smartphone telefoniere und dabei andere Dinge tue, werde ich von der Unterhaltung mitgerissen und achte nicht darauf was ich gerade eigentlich tue.

10. Die Zeit, die ich mit meinem Smartphone verbringe, hat in den letzten 12 Monaten zugenommen.

11. Ich habe mein Smartphone benutzt, um mit anderen zu sprechen, als ich mich isoliert fühlte.

12. Ich habe versucht, weniger Zeit mit meinem Smartphone zu verbringen, aber es gelingt mir nicht.

13. Ich finde es schwierig, mein Smartphone auszuschalten.

14. Ich bin besorgt, wenn ich einige Zeit nicht meine Nachrichten kontrollieren kann oder mein Smartphone nicht eingeschaltet habe.

15. Ich träume häufig von meinem Smartphone.

16. Meine Freunde und Familie beschweren sich über meine Smartphonenutzung.

17. Wenn ich kein Smartphone hätte, wäre es für meine Freunde schwierig, mit mir in Kontakt zu treten.

18. Meine Produktivität ist als direkte Folge der Zeit, die ich mit dem Smartphone verbringe, gesunken.

19. Ich habe Wehwehchen, die mit der Benutzung meines Smartphones zusammenhängen.

20. Ich bin für längere Zeiträume als vorgesehen mit dem Smartphone beschäftigt.

21. Es gibt Zeiten, in denen ich lieber das Smartphone benutze, als mich mit anderen dringenderen Dingen zu befassen.

22. Ich komme oft zu spät zu Terminen, weil ich mit dem Smartphone beschäftigt bin, obwohl ich es nicht sollte.

23. Ich werde gereizt, wenn ich mein Smartphone für Besprechungen, beim Abendessen oder im Kino ausschalten muss.

24. Mir wurde gesagt, dass ich zu viel Zeit mit meinem Smartphone verbringe.

25. Mehr als einmal war ich in Schwierigkeiten, weil mein Mobiltelefon während einer Besprechung, eines Vortrags oder im Theater ausgeschaltet war.

26. Meine Freunde mögen es nicht, wenn mein Smartphone ausgeschaltet ist.

27. Ich fühle mich ohne mein Smartphone verloren.

\section{References}

1. Kuyulu, I.; Beltekin, E. Relationship between Smartphone Addiction and Personality Traits. Asian J. Educ. 2020, 6, 304-313. [CrossRef]

2. Tekin, C.; Gunes, G.; Colak, C. Adaptation of Problematic Mobile Phone Use Scale to Turkish: A Validity and Reliability Study. Med-Science 2014, 3, 1361-1381. [CrossRef]

3. Statista. Anteil der Smartphone-Nutzer in Deutschland in den Jahren 2012 bis 2020 [Proportion of smartphone users in Germany in the years 2012 to 2020]; Statista GmbH: Hamburg, Germany, 2021; Available online: https:/ / de.statista.com/statistik/daten/studie/ 585883/umfrage/anteil-der-smartphone-nutzer-in-deutschland/ (accessed on 20 October 2021).

4. Bayhan, P.; Işıtan, S. Ergenlik Döneminde İlişkiler: Akran ve Romantik İlişkilere Genel Bakış [Relationships in Adolescence: An Overview of Peer and Romantic Relationships]. J. Soc. Policy 2010, 20, 33-44. Available online: https://dergipark.org.tr/en/ $\mathrm{pub} / \mathrm{spcd} /$ issue/21108/227337 (accessed on 30 September 2021). 
5. Noyan, C.O.; Darçın, A.; Nurmedov, S.; Yılmaz, O.; Dilbaz, N. Akilli Telefon Bagimliligi Olceginin Kisa Formunun Universite Ogrencilerinde Turkce Gecerlilik ve Guvenilirlik Calismasi [Validity and Reliability of the Turkish Version of the Smartphone Addiction Scale-Short Version among University Students]. Anadolu Psikiyatr. Derg. 2015, 16, 73-81. [CrossRef]

6. Bian, M.; Leung, L. Linking Loneliness, Shyness, Smartphone Addiction Symptoms, and Patterns of Smartphone Use to Social Capital. Soc. Sci. Comput. Rev. 2015, 33, 61-79. [CrossRef]

7. Kuss, D.J.; Kanjo, E.; Crook-Rumsey, M.; Kibowski, F.; Wang, G.Y.; Sumich, A. Problematic Mobile Phone Use and Addiction Across Generations: The Roles of Psychopathological Symptoms and Smartphone Use. J. Technol. Behav. Sci. 2018, 3, 141-149. [CrossRef]

8. Kwon, M.; Lee, J.Y.; Won, W.Y.; Park, J.W.; Min, J.A.; Hahn, C.; Gu, X.; Choi, J.-H.; Kim, D.J. Development and Validation of a Smartphone Addiction Scale (SAS). PLoS ONE 2013, 8, e56936. [CrossRef]

9. Lin, Y.H.; Chang, L.R.; Lee, Y.H.; Tseng, H.W.; Kuo, T.B.J.; Chen, S.H. Development and Validation of the Smartphone Addiction Inventory (SPAI). PLoS ONE 2014, 9, e98312. [CrossRef]

10. Skierkowski, D.; Wood, R.M. To Text or Not to Text? The Importance of Text Messaging among College-Aged Youth. Comput. Hum. Behav. 2012, 28, 744-756. [CrossRef]

11. Panova, T.; Carbonell, X. Is Smartphone Addiction Really an Addiction? J. Behav. Addict. 2018, 7, 252-259. [CrossRef]

12. Cheever, N.; Rosen, L.; Carrier, L.M.; Chavez, A. Out of Sight Is Not Out of Mind: The Impact of Restricting Wireless Mobile Device Use on Anxiety Levels among Low, Moderate and High Users. Comput. Hum. Behav. 2014, 37, 290-297. [CrossRef]

13. King, A.L.; Valença, A.M.; Silva, A.C.; Baczynski, T.; Carvalho, M.R.; Nardi, A.E. Nomophobia: Dependency on Virtual Environments or Social Phobia? Comput. Hum. Behav. 2013, 29, 140-144. [CrossRef]

14. Billieux, J.; Maurage, P.; Lopez-Fernandez, O.; Kuss, D.J.; Griffiths, M.D. Can Disordered Mobile Phone Use Be Considered a Behavioral Addiction? An Update on Current Evidence and a Comprehensive Model for Future Research. Curr. Addict. Rep. 2015, 2, 156-162. [CrossRef]

15. Elhai, J.D.; Levine, J.C.; Dvorak, R.D.; Hall, B.J. Non-Social Features of Smartphone Use Are Most Related to Depression, Anxiety and Problematic Smartphone use. Comput. Hum. Behav. 2017, 69, 75-82. [CrossRef]

16. Billieux, J. Problematic Use of the Mobile Phone: A Literature Review and a Pathways Model. Curr. Psychiatry Rev. 2012, 8, 299-307. [CrossRef]

17. Darcin, A.E.; Noyan, C.; Nurmedov, S.; Yilmaz, O.; Dilbaz, N. Smartphone Addiction in Relation with Social Anxiety and Loneliness Among University Students in Turkey. Eur. Psychiatry 2015, 30, 505. [CrossRef]

18. Chiu, S.I. The Relationship between Life Stress and Smartphone Addiction on Taiwanese University Student: A Mediation Model of Learning Self-Efficacy and Social Self-Efficacy. Comput. Hum. Behav. 2014, 34, 49-57. [CrossRef]

19. Fidan, H. Development and Validity of Mobile Addiction Scale: Components Model Approach. Addicta 2016, 3, 433-469. [CrossRef]

20. Long, J.; Liu, T.Q.; Liao, Y.H.; Qi, C.; He, H.Y.; Chen, S.B.; Billieux, J. Prevalence and Correlates of Problematic Smartphone use in a Large Random Sample of Chinese Undergraduates. BMC Psychiatry 2016, 16, 408. [CrossRef]

21. Gross, E.F. Adolescent Internet Use: What We Expect, What Teens Report. J. Appl. Dev. Psychol. 2004, 25, 633-649. [CrossRef]

22. Baggio, S.; Starcevic, V.; Studer, J.; Simon, O.; Gainsbury, S.M.; Gmel, G.; Billieux, J. Technology-Mediated Addictive Behaviors Constitute a Spectrum of Related yet Distinct Conditions: A Network Perspective. Psychol. Addict. Behav. 2018, 32, 564-572. [CrossRef]

23. Kuss, D.J.; Griffiths, M. Internet Addiction in Psychotherapy, 1st ed.; Palgrave Pivot: London, UK, 2015; pp. 54-104. [CrossRef]

24. Lopez-Fernandez, O.; Kuss, D.J.; Griffiths, M.D.; Billieux, J. The Conceptualization and Assessment of Problematic Mobile Phone Use. In Encyclopedia of Mobile Phone Behavior, 1st ed.; Yan, Z., Ed.; Information Science Reference: Hershey, PA, USA, 2015; Volume 1-3, pp. 591-606. [CrossRef]

25. Oulasvirta, A.; Rattenbury, T.; Ma, L.; Raita, E. Habits Make Smartphone Use More Pervasive. Pers. Ubiquitous Comput. 2012, 16, 105-114. [CrossRef]

26. Andreassen, C.S. Online Social Network Site Addiction: A Comprehensive Review. Curr. Addict. Rep. 2015, 2, 175-184. [CrossRef]

27. Marino, C.; Gini, G.; Vieno, A.; Spada, M.M. The Associations between Problematic Facebook Use, Psychological Distress and Well-Being among Adolescents and Young Adults: A Systematic Review and Meta-Analysis. J. Affect. Disord. 2018, 226, $274-281$. [CrossRef]

28. Pivetta, E.; Harkin, L.; Billieux, J.; Kanjo, E.; Kuss, D.J. Problematic Smartphone Use: An Empirically Validated Model. Comput. Hum. Behav. 2019, 100, 105-117. [CrossRef]

29. Markowetz, A. Digitaler Burnout: Warum Unsere Permanente Smartphone-Nutzung Gefährlich Ist [Digital Burnout: Why Our Constant Smartphone Use Is Dangerous], 1st ed.; Droemer Knaur Verlag: München, Deutschland, 2015.

30. Bianchi, A.; Phillips, J.G. Psychological Predictors of Problem Mobile Phone Use. Cyberpsychol. Behav. Soc. Netw. 2005, 8, 39-51. [CrossRef]

31. World Health Organization. Public Health Implications of Excessive Use of the Internet, Computers, Smartphones and Similar Electronic Devices: Meeting report [Conference session]. In Proceedings of the Foundation for Promotion of Cancer Research, National Cancer Research Centre, Tokyo, Japan, 27-29 August 2015. Available online: http://apps.who.int/iris/bitstream/ handle/10665/184264/9789241509367_eng.pdf?sequence=1 (accessed on 20 September 2021). 
32. Mache, S.; Harth, V. Digitale Transformation in der Arbeitswelt und Psychische Gesundheit [Digital transformation in the world of work and mental health]. Zbl. Arb. 2020, 70, 180-184. [CrossRef]

33. Stadin, M.; Nordin, M.; Broström, A.; Magnusson Hanson, L.L.; Westerlund, H.; Fransson, E.I. Information and Communication Technology Demands at Work: The Association with Job Strain, Effort-Reward Imbalance and Self-Rated Health in Different Socio-Economic Strata. Int. Arch. Occup. Environ. Health 2016, 89, 1049-1058. [CrossRef]

34. Haug, S.; Castro, R.P.; Kwon, M.; Filler, A.; Kowatsch, T.; Schaub, M.P. Smartphone Use and Smartphone Addiction among Young People in Switzerland. J. Behav. Addict. 2015, 4, 299-307. [CrossRef]

35. Lemola, S.; Perkinson-Gloor, N.; Brand, S.; Dewald-Kaufmann, J.F.; Grob, A. Adolescents' Electronic Media Use at Night, Sleep Disturbance and Depressive Symptoms in the Smartphone Age. J. Youth Adolesc. 2015, 44, 405-418. [CrossRef]

36. Thomeée, S.; Harenstam, A.; Hagberg, M. Mobile Phone Use and Stress, Sleep Disturbances, and Symptoms of Depression among Young Adults-A Prospective Cohort Study. BMC Public Health 2011, 11, 66. [CrossRef] [PubMed]

37. Sampasa-Kanyinga, H.; Lewis, R.F. Frequent Use of Social Networking Sites Is Associated with Poor Psychological Functioning Among Children and Adolescents. Cyberpsychol. Behav. Soc. Netw. 2015, 18, 380-385. [CrossRef] [PubMed]

38. Lee, H.; Ahn, H.; Choi, S.; Choi, W. The SAMS: Smartphone Addiction Management System and Verification. J. Med. Syst. $2014,38,1$. [CrossRef] [PubMed]

39. Grant, J.E.; Lust, K.; Chamberlain, S.R. Problematic Smartphone Use Associated with Greater Alcohol Consumption, Mental Health Issues, Poorer Academic Performance, and Impulsivity. J. Behav. Addict. 2019, 8, 335-342. [CrossRef] [PubMed]

40. Smetaniuk, P. A Preliminary Investigation into the Prevalence and Prediction of Problematic Cell Phone Use. J. Behav. Addict. 2014, 3, 41-53. [CrossRef]

41. Demirci, K.; Akgonul, M.; Akpinar, A. Relationship of Smartphone Use Severity with Sleep Quality, Depression, and Anxiety in University Students. J. Behav. Addict. 2015, 4, 85-92. [CrossRef]

42. Elhai, J.D.; Levine, J.C.; Dvorak, R.D.; Hall, B.J. Fear of Missing Out, Need for Touch, Anxiety and Depression Are Related to Problematic Smartphone Use. Comput. Hum. Behav. 2016, 63, 509-516. [CrossRef]

43. Harwood, J.; Dooley, J.J.; Scott, A.J.; Joiner, R. Constantly Connected-The Effects of Smart-Devices on Mental Health. Comput. Hum. Behav. 2014, 34, 267-272. [CrossRef]

44. Kim, R.; Lee, K.J.; Choi, Y.J. Mobile Phone Overuse among Elementary School Students in Korea: Factors Associated with Mobile Phone Use as a Behavior Addiction. J. Addict. Nurs. 2015, 26, 81-85. [CrossRef]

45. Kim, J.; Seo, M.; David, P. Alleviating Depression Only to Become Problematic Mobile Phone Users: Can Face-to-Face Communication Be the Antidote? Comput. Hum. Behav. 2015, 51, 440-447. [CrossRef]

46. Kempf, C.A.; Ehrhard, K.A.; Stoner, S.C. Evaluation of Obsessive-Compulsive Symptoms in Relation to Smartphone Use. Ment. Health Clin. 2020, 10, 44-48. [CrossRef] [PubMed]

47. Fırat, S.; Gül, H.; Sertçelik, M.; Gül, A.; Gürel, Y.; Kılıç, B.G. The Relationship between Problematic Smartphone Use and Psychiatric Symptoms among Adolescents Who Applied to Psychiatry Clinics. Psychiatry Res. 2018, 270, 97-103. [CrossRef] [PubMed]

48. Im, K.G.; Hwang, S.J.; Choi, M.I.; Seo, N.R.; Byun, J.N. The Correlation between Smartphone Addiction and Psychiatric Symptoms in College Students. J. Korean Soc. Sch Health 2013, 26, 124-131.

49. Yu, M.O.; Ju, S.J.; Kim, J.H. A Study on Smartphone Addiction, Mental health and Impulsiveness For High School Students at Korea. J. Digit. Converg. 2014, 12, 409-418. [CrossRef]

50. Baek, H.W.; Shin, Y.M.; Shin, K.M. Emotional and Behavioral Problems Related to Smartphone Overuse in Elementary School Children. J. Korean Neuropsychiatr. Assoc. 2014, 53, 320-326. [CrossRef]

51. Tayhan Kartal, F.; Yabancı Ayhan, N. Relationship between Eating Disorders and Internet and Smartphone Addiction in College Students. Eat Weight Disord. 2021, 26, 1853-1862. [CrossRef]

52. Aparicio-Martinez, P.; Perea-Moreno, A.J.; Martinez-Jimenez, M.P.; Redel-Macías, M.D.; Pagliari, C.; Vaquero-Abellan, M. Social Media, Thin-Ideal, Body Dissatisfaction And Disordered Eating Attitudes: An Exploratory Analysis. Int. J. Environ. 2019, $16,4177$. [CrossRef]

53. Quick, V.M.; Byrd-Bredbenner, C. Disordered Eating, Socio-Cultural Media Influencers, Body Image, and Psychological Factors among a Racially/Ethnically Diverse Population of College Women. Eat. Behav. 2014, 15, 37-41. [CrossRef]

54. Matar Boumosleh, J.; Jaalouk, D. Depression, Anxiety, and Smartphone Addiction in University Students-A cross Sectional Study. PLoS ONE 2017, 12, e0182239. [CrossRef]

55. Kotov, R.; Gamez, W.; Schmidt, F.; Watson, D. Linking Big Personality Traits to Anxiety, Depressive, and Substance Use Disorders: A Meta-Analysis. Psychol. Bull. 2010, 136, 768-821. [CrossRef]

56. Malouff, J.M.; Thorsteinsson, E.B.; Schutte, N.S. The Relationship between the Five-Factor Model of Personality and Symptoms of Clinical Disorders: A Meta-Analysis. J. Psychopathol. Behav. Assess. 2005, 27, 101-114. [CrossRef]

57. Herpertz, S.C. Temperament und Persönlichkeit [Temperament and personality]. In Entwicklungen der Psychiatrie, 1st ed.; Schneider, F., Ed.; Springer: Berlin/Heidelberg, Germany, 2006; pp. 231-238. [CrossRef]

58. McCrae, R.R.; Costa, P.T., Jr. Empirical and Theoretical Status of the Five-Factor Model of Personality Traits. In The SAGE Handbook of Personality Theory and Assessment; Boyle, G., Matthews, G., Saklofske, D., Eds.; SAGE Publications: Thousand Oaks, CA, USA, 2008; Volume 1, pp. 273-294. [CrossRef] 
59. Marengo, D.; Sindermann, C.; Haeckel, D.; Settanni, M.; Montag, C. The Association between the Big Five Personality Traits and Smartphone Use Disorder: A Meta-Analysis. J. Behav. Addict. 2020, 9, 534-550. [CrossRef]

60. McCrae, R.R.; Costa, P.T., Jr. A Five-Factor Theory of Personality. In Handbook of Personality: Theory and Research, 2nd ed.; Pervin, L.A., John, O.P., Eds.; Guilford: New York, NY, USA, 1999; pp. 139-153.

61. Arpaci, I.; Unver, T.K. Moderating Role of Gender in the Relationship between Big Five Personality Traits and Smartphone Addiction. Psychiatr. Q. 2020, 91, 577-585. [CrossRef]

62. Butt, S.; Phillips, J.G. Personality and Self-Reported Mobile Phone Use. Comput. Hum. Behav. 2008, 24, 346-360. [CrossRef]

63. Hussain, Z.; Griffiths, M.D.; Sheffield, D. An Investigation into Problematic Smartphone Use: The Role of Narcissism, Anxiety, and Personality Factors. J. Behav. Addict. 2017, 6, 378-386. [CrossRef]

64. Montag, C. Homo Digitalis: Smartphones, Soziale Netzwerke und das Gehirn [Homo Digitalis: Smartphones, Social Networks and the Brain], 1st ed.; Springer Fachmedien Wiesbaden: Wiesbaden, Germany, 2018; pp. 13-28. [CrossRef]

65. Augner, C.; Hacker, G.W. Associations between Problematic Mobile Phone Use and Psychological Parameters in Young Adults Int. J. Public Health 2012, 57, 437-441. [CrossRef]

66. Ehrenberg, A.; Juckes, S.; White, K.M.; Walsh, S.P. Personality and Self-Esteem as Predictors of Young People's Technology Use. Cyberpsychol. Behav. Soc. Netw. 2008, 11, 739-741. [CrossRef]

67. Foerster, M.; Roser, K.; Schoeni, A.; Röösli, M. Problematic Mobile Phone Use in Adolescents: Derivation of a Short Scale MPPUS-10. Int. J. Public Health 2015, 60, 277-286. Available online: https:/ /10.1007/s00038-015-0660-4 (accessed on 30 September 2021). [CrossRef]

68. Takao, M. Problematic Mobile Phone Use and Big-Five Personality Domains. Indian J. Community Med. 2014, 39, 111-113. [CrossRef]

69. Montag, C.; Błaszkiewicz, K.; Lachmann, B.; Andone, I.; Sariyska, R.; Trendafilov, B.; Reuter, M.; Markowetz, A. Correlating Personality and Actual Phone Usage: Evidence From Psychoinformatics. J. Individ. Differ. 2014, 35, 158-165. [CrossRef]

70. Billieux, J.; Van der Linden, M.; Rochat, L. The Role of Impulsivity in Actual and Problematic Use of the Mobile Phone. Appl. Cogn. Psychol. 2008, 22, 1195-1210. [CrossRef]

71. Cocoradă, E.; Maican, C.I.; Cazan, A.M.; Maican, M.A. Assessing the Smartphone Addiction Risk and Its Associations with Personality Traits among Adolescents. Child Youth Serv. Rev. 2018, 93, 345-354. [CrossRef]

72. Horwood, S.; Anglim, J. Personality and Problematic Smartphone Use: A Facet-Level Analysis Using the Five Factor Model and HEXACO Frameworks. Comput. Hum. Behav. 2018, 85, 349-359. [CrossRef]

73. Ahn, J.; Jung, Y. The Common Sense of Dependence on Smartphone: A Comparison between Digital Natives and Digital Immigrants. New Media Soc. 2016, 18, 1236-1256. [CrossRef]

74. Prensky, M. Digital Natives, Digital Immigrants Part 2: Do They Really Think Differently? Horizon 2001, 9, 1-6. [CrossRef]

75. Dimock, M. Defining Generations: Where Millennials End and Generation Z Begins; Pew Research Center: Washington, DC, USA, 2019; Available online: https:/ /www.pewresearch.org/fact-tank/2019/01/17/where-millennials-end-and-generation-z-begins / (accessed on 20 October 2021).

76. Bhattacharya, K.; Ghosh, A.; Monsivais, D.; Dunbar, R.I.M.; Kaski, K. Sex Differences in Social Focus across the Life Cycle in Humans. R. Soc. Open Sci. 2016, 3, 1-9. [CrossRef]

77. Petermann, F.; Petermann, U. Jugendalter [Youth age]. Kindh. Und Entwickl. 2012, 21, 194-197. [CrossRef]

78. Echeburúa, E.; De Corral, P. Adicción a las Nuevas Tecnologías ya las Redes Sociales en Jóvenes: Un Nuevo Reto [Addiction to New Technologies and Social Networks in Young People: A New Challenge]. Adicciones 2010, 22, 91-95. [CrossRef]

79. Cerniglia, L.; Guicciardi, M.; Sinatra, M.; Monacis, L.; Simonelli, A.; Cimino, S. The Use of Digital Technologies, Impulsivity and Psychopathological Symptoms in Adolescence. Behav. Sci. 2019, 9, 82. [CrossRef]

80. Döring, N.; Bortz, J. Forschungsmethoden und Evaluation [Research Methods and Evaluation]; Springer: Wiesbaden, Germany, 2016.

81. Field, A. Discovering Statistics Using IBM SPSS Statistics; Sage: Los Angeles, CA, USA, 2013.

82. Rammstedt, B.; John, O.P. Measuring Personality in One Minute or Less: A 10-Item Short Version of the Big Five Inventory in English and German. J. Res. Pers. 2007, 41, 203-212. [CrossRef]

83. Tritt, K.; von Heymann, F.; Zaudig, M.; Zacharias, I.; Söllner, W.; Loew, T. Entwicklung des Fragebogens ICD-10-Symptom-Rating (ISR) [Development of the ICD-10 Symptom Rating (ISR) questionnaire]. Z. Psychosom. Med. Psychother. 2008, 54, 409-418. [CrossRef]

84. Behr, D.; Braun, M.; Dorer, B. Messinstrumente in Internationalen Studien [Measurement Instruments in International Studies]; GESIS-Leibniz-Institut für Sozialwissenschaften (GESIS Survey Guidelines): Mannheim, Germany, 2015; Available online: https://www.gesis.org/gesis-survey-guidelines/instruments/fragebogenkonstruktion/messinstrumente-international (accessed on 20 October 2021).

85. Cohen, J. Statistical Power Analysis for the Behavioral Sciences, 2nd ed.; Lawrence Erlbaum Associates: Hillsdale, NJ, USA, 1988.

86. John, O.P.; Donahue, E.M.; Kentle, R.L. Big Five Inventory. In The Big Five Inventory_Versions 4a and 54; University of California at Berkeley, Institute of Personality and Social Research: Berkeley, CA, USA, 1991.

87. Rammstedt, B.; Kemper, C.J.; Klein, M.C.; Beierlein, C.; Kovaleva, A. Eine Kurze Skala zur Messung der fünf Dimensionen der Persönlichkeit: Big-Five-Inventory-10 (BFI-10) [A Short Scale to Measure the Five Dimensions of Personality: Big-Five-Inventory10 (BFI-10).]. GESIS-Work. Pap. 2012, 23, 32. 
88. Murdock, K.K. Texting While Stressed: Implications for Students' Burnout, Sleep, and Well-Being. Psychol. Pop. Media Cult. 2013, 2, 207-221. [CrossRef]

89. Müller, K.W.; Koch, A.; Dickenhorst, U.; Beutel, M.E.; Duven, E.; Wölfling, K. Addressing the Question of Disorder-Specific Risk Factors of Internet Addiction: A Comparison of Personality Traits in Patients with Addictive Behaviors and Comorbid Internet Addiction. Biomed Res. Int. 2013, 2013, 546342. [CrossRef]

90. Darcin, A.E.; Kose, S.; Noyan, C.O.; Nurmedov, S.; Y1lmaz, O.; Dilbaz, N. Smartphone Addiction and Its Relationship with Social Anxiety and Loneliness. Behav. Inf. Technol. 2016, 35, 520-525. [CrossRef]

91. Berk, L.E. Entwicklungspsychologie [Developmental Psychology], 5th ed.; Pearson Deutschland GmbH: München, Germany, 2011; Volume 4049.

92. Wall Street Journal Staff. Facebook's Documents About Instagram and Teens, Published; Dow Jones \& Company Inc. (In The Wall Street Journal): Monmouth Junction, NJ, USA, 2021; Available online: https:/ / www.wsj.com/articles/facebook-documentsinstagram-teens-11632953840 (accessed on 20 October 2021). 